Business Research

Elsevier Editorial System(tm) for Journal of

Manuscript Draft

Manuscript Number: JBR-D-19-01664R2

Title: The effect of entrepreneurial orientation on firm performance: a multigroup analysis comparing China, Mexico, and Spain

Article Type: Full length article

Keywords: Entrepreneurial orientation; firm performance; PLS; MICOM; multigroup analysis; China-Mexico-Spain

Corresponding Author: Dr. Felipe Hernández-Perlines, Dr.

Corresponding Author's Institution: Universidad de Castilla-La Mancha

First Author: Rodrigo Basco, PhD

Order of Authors: Rodrigo Basco, PhD; Felipe Hernández-Perlines, Dr.;

María Rodríguez-García

Abstract: This article analyzes firm entrepreneurial orientation across different contexts. Applying institutional theory to entrepreneurship proves the different role of the entrepreneurial orientation dimensions depending on the context. The sample for this study is composed of both small and medium-sized firms from three countries: China, Mexico, and Spain. In the means of testing our hypothesis and thus quantifying the moderating effect of context, a structural equation model PLS-SEM technique and, specifically, a multigroup analysis approach has been implemented. The results have led us to confirm an overall positive effect of entrepreneurial orientation on firm performance regardless of firm context. However, the context of a firm certainly acts as a moderator by determining the effect of entrepreneurial orientation on firm performance. This effect is explained by the conditioning power of context over innovation, proactiveness, and risk-taking, the three main factors defining firm entrepreneurial orientation across contexts. 


\section{Response to Editors}

Dear Domingo E. Ribeiro,

Associate Editor

Journal of Business Research,

Toledo, 8 September 2019

I attach the paper entitled "The Effect of Entrepreneurial Orientation on Firm

Performance: A Multigroup Analysis Comparing China, Mexico, and Spain”, whose authors they are: Rodrigo Basco, Felipe Hernández-Perlines and María Rodríguez-García which has been formatted according to the requirements of Journal.

Thank you very much.

Best regards.

Felipe Hernández-Perlines

University of Castilla-La Mancha 
Manuscript title:

The Effect of Entrepreneurial Orientation on Firm Performance: A Multigroup Analysis Comparing China, Mexico, and Spain

Rodrigo Basco

Sheikh Saoud bin Khalid bin Khalid Al-Qassimi Family Business- American University of Sharjah

Felipe Hernández-Perlines, Department of Business Administration-University of Castilla-La Mancha

María Rodríguez-García, ESIC Business \& Marketing School

Rodrigo Basco, Sheikh Saoud bin Khalid bin Khalid Al-Qassimi Family Business American University, United Arab Emirates (bascorodrigo@gmail.com)

Please send correspondence to: Felipe Hernández-Perlines (corresponding author), University of Castilla-La Mancha, San Pedro Mártir, s/n, Toledo, Spain, +34925268800, ext. 5161 (Felipe.HPerlines@uclm.es);

María Rodríguez-García, ESIC Business \& Marketing School, Spain

(maria.rodriguez.investigadorVAL@esic.edu) 


\title{
The Effect of Entrepreneurial Orientation on Firm Performance: A Multigroup Analysis Comparing China, Mexico, and Spain
}

\begin{abstract}
This article analyzes firm entrepreneurial orientation across different contexts. In the light of the existing literature on entrepreneurship and institutional theory, it departs from the hypothesis that the context in which firms operate determines the importance of each dimension comprised in the multidimensional concept of entrepreneurship orientation, thus moderating its effect of on firm performance. The sample for this study is composed of both small and medium-sized firms from three countries: China, Mexico, and Spain. In the means of testing our hypothesis and thus quantifying the moderating effect of context, a structural equation model PLS-SEM technique and, specifically, a multigroup analysis approach has been implemented. The results have led us to confirm an overall positive effect of entrepreneurial orientation on firm performance regardless of firm context. However, the context of a firm certainly acts as a moderator by determining the effect of entrepreneurial orientation on firm performance. This effect is explained by the conditioning power of context over innovation, proactiveness, and risk-taking, the three main factors defining firm entrepreneurial orientation across contexts.
\end{abstract}

KEYWORDS: Entrepreneurial orientation; firm performance; PLS; MICOM; multigroup analysis; China-Mexico-Spain 


\section{Introduction}

In the last 30 years, entrepreneurial orientation has been one of the most relevant topics in Business and Management research (Wales, Monsen, \& McKelvie, 2013; Cavusgil \& Knight, 2015). Hence, an economic approach to entrepreneurship has developed around two main dimensions: risk (Knight, 1921), and innovation (Schumpeter, 1934), drawing on the creative destruction process as a source of national and regional economic development (Ferreira, Fernandes, \& Kraus, 2019; Wong, Ho, \& Autio, 2005). The necessary condition for creative destruction to occur within a given geographical space is the existence of an entrepreneurial orientation at an individual as well as at a firm level. In this study, we have sought to connect entrepreneurial orientation with corporate entrepreneurship by defining an entrepreneurial performance adopting proactive and somewhat risky innovations (Miller, 1983). We conceive the concept of entrepreneurial orientation as informed by three main dimensions: risk-taking, proactiveness, and innovativeness. That is, we understand such concept as a type b, secondorder composite (for more information see Hansen, Deitz, Tokman, Marino, \& Weaver, 2011; Covin \& Wales, 2012, Hernández-Perlines, 2018).

The main motivation for this work is that, despite numerous studies analyzing the concept of entrepreneurial orientation (EO hereafter) (e.g., Kreiser, Marino, \&Weaver, 2002; Stetz, Howell, Stewart, Blair, \&Fottler, 2000; Wiklund \&Shepherd, 2005), and its relation to firm performance (e.g., Engelen, Gupta, Strenger, \&Brettel, 2015; Lechner \& Gudmundsson, 2014), no conclusive results in this sense have been put forward to this day. Additionally, although the universality of entrepreneurial constructs has been proven (e.g., Kreiser et al., 2002; Stetz et al., 2000; Wiklund \& Shepherd, 2005), the importance of the aforementioned dimensions informing the concept shows a considerable degree of variation across different cultural and institutional contexts (Kreiser, Marino, Dickson, \& Weaver, 2010; Lee \& 
Peterson, 2000). This article is aimed at addressing these research gaps by contextualizing (Basco, 2017) the concept of EO and its effect on firm performance. By doing so, a solid contribution is intended to the advancement of research in entrepreneurial orientation by analyzing the effect of context (Shirokova, Bogatyreva, Beliaeva, \& Puffer, 2016) and recognizing the importance of its social and cultural dimensions in business management research (Ferreira, Fernandes, \& Kraus, 2019).

Since entrepreneurship is legitimized and encouraged by a set of cultural beliefs and socio-economic institutions (Reynolds, Hay, \& Camp, 1999), a new focus on firm context seems appropriate as a response to the urgings of several authors (e.g., Covin \&Miller, 2014; Kiss, Danis, \& Cavusgil, 2012; Veciana \& Urbano, 2008; Welter, 2011). Indeed a given cultural and institutional environment may stress the importance of some EO dimensions over others, while moderating the relationship between entrepreneurial orientation and firm performance. Consequently, our research questions are stated as follows: Does EO influence firm performance? Does the importance of each EO dimension vary across countries? To what extent does the context of firm operation affect the relationship between EO and firm performance?

For this purpose, the use of an institutional approach has proven useful to theorize how firms differ across countries in both the balance composition of EO dimensions and the relationship between EO and firm performance. From a theoretical perspective, variance in the importance of each EO dimension is possible (Lumpkin \& Dess, 1996a). Therefore, we can hypothesize the existence of multiple EO profiles which, as a consequence of institutional and environmental pressure, show a differing balance between their innovation, proactiveness, and risk-taking dimensions. Additionally, further developments of the previous 
arguments have lead to the assumption that national contexts act as a moderators altering the effect of entrepreneurial orientation on firm performance.

To test our hypotheses, we have conducted a research in China, Mexico, and Spain, with an outcome of 330 responses from CEOs (114 Chinese, 102 Mexican, and 114 Spanish). Each of these countries' cultural and institutional environment have specific features. Thus, for the purpose of analyzing the resulting data and contrasting our hypothesis, we used a structural equation model PLS-SEM technique through SmartPLS 3.2.8 software (Ringle, Wende, \& Becker, 2015). We additionally applied a Method for Measurement Invariance of Composite Models (MICOM), as well as a multigroup analysis approach in order to analyze the moderating effect of context multigroup.

In the light of our findings, we have concluded that not all EO dimensions (innovativeness, proactiveness and risk-taking) have the same importance across countries, forming a type b, second-order composite (Henseler, Hubona, \& Ray, 2016). In order words, substantial differences arise from each context. In China, innovativeness and proactiveness are the most relevant dimensions of the concept itself. In contrast, in Spain, all three dimensions have a similar degree of importance in the composition of EO. Finally, in Mexico, the most important dimension is innovativeness. This switching potential in the importance of each dimension across contexts is in line with previous studies in other settings (e.g., Yusuf, 2002; Wales, Gupta, \& Mousa, 2013; Kreiser., Marino, Kuratko, \& Weaver, 2013), revealing the influence of context in the concept of EO. Additionally, we've found conclusive evidence that context moderates the relationship between EO and firm performance.

\section{Theoretical framework and hypotheses}

\subsection{Entrepreneurial orientation dimensions and firm performance}


Entrepreneurial orientation has produced a great deal of knowledge due to the attention received from researchers in the business and management field (Covin \& Slevin, 1989; Kropp, Lindsay, \& Shoham2006; Covin \& Miller, 2014; Rigtering, Eggers, Kraus, \& Chang, 2017; Hernández-Perlines, 2018). Indeed, a consolidated research tradition has revolved around this concept (Lomberg, Urbig, Marino, \& Dickson, 2017). Notably, Lumpkin and Dess (2001) have succeeded in linking EO with a firm's tendency to seek new business opportunities. In this sense, an entrepreneurial firm is one that engages in proactive and risky innovation to tackle new markets (Miller, 1983). Therefore, at the core of entrepreneurial orientation are innovativeness, proactiveness, and risk-taking behavior, developed and driven by the top management team (Poon, Ainuddin, \& Junit, 2006) as the determining factors of a firm's competitive strategy (Rigtering et al., 2017).

Aligned with the above reasoning, three main dimensions are considered to define the concept of EO: risk-taking, proactiveness, and innovativeness (Wales, 2016; Wales et al., 2013; Rigtering et al., 2017). Despite the existence of further conceptualizations of entrepreneurial orientation, either with additional (e.g., Lumpkim \& Dess, 1996) or fewer dimensions (e.g., Merz \& Sauber, 1995), here we follow Lomberg et al. (2017), who consider risk-taking, proactiveness, and innovativeness the best-defining features of the concept of entrepreneurial orientation. Risk-taking involves the implementation of bold actions engaging significant levels of resources without any certainty regarding the potential profits (Lumpkin \&Dess, 1996a; Kraus., Rigtering, Hughes, \& Hosman, 2012; Rigtering et al., 2017). Proactiveness involves the launch of new products and services before competitors (Anderson, Kreiser, Kuratko, Hornsby, \& Eshima, 2015; Filser, Eggers, Kraus, \& Málovic, 2014). Proactiveness, on its part, requires the anticipation of future needs and desires, seeking the advantage of pioneering opportunities in new business ventures (Covin \& Slevin, 1989; Lumpkin \&Dess, 1996a; Rigtering et al., 2017). Finally, innovativeness involves a creative 
process supporting experimentation and new ideas (Miller \& Friesen, 1983; Kropp et al. 2006; Chandra, Styles \& Wilkinson, 2009; Covin et al., 2016).

Therefore, the notion of EO can be stated to capture a firm's entrepreneurial behavior through innovation, proactivity and risk-taking. Even though entrepreneurial orientation can be conceptualized in different ways (this debate can be followed in Lomberg et al., 2017), we shall be applying that which considers entrepreneurial orientation as multidimensional (Lumpkin \& Dess, 1996a), integrating innovativeness, proactiveness, and risk-taking in a higher order compound (Covin \&Wales, 2012; Hernández-Perlines, Moreno-García, \& Yáñez-Araque, 2019). This approach makes it possible to analyze the direct effects of entrepreneurial orientation on firm performance, as well as the indirect ones of innovation, proactivity and risk assumption on firm performance individually (Hernández-Perlines, Moreno-García, \& Yáñez-Araque, 2016).

In line with this, Kraus et al. (2012) point out that entrepreneurial orientation is a good indicator of proper firm management. From a theoretical as well as an empirical point of view, the existing research indicates that entrepreneurial orientation has a positive influence on firm performance (e.g., Filser et al., 2014; Hernández-Perlines, 2018; Poon et al., 2006; Saeed, Yousafzai, \& Engelen, 2014; Shirokova et al., 2016; Wales et al., 2013). Therefore, our first hypothesis shall be formulated as follows:

Hypothesis 1: Entrepreneurial orientation influences firm performance positively.

\subsection{Contextualizing EO and its effect on firm performance}

Context can explain the extent to which EO may affect firm performance given its decisive impact on each dimension of both entrepreneurial orientation and composite entrepreneurial orientation. Such influence has been considered from the first studies carried out on this subject (Miller, 1983; Covin \& Slevin, 1989; Lumpkim \& Dess, 1996a). Stetz et al. (2000), 
for instance, consider the dimensions of EO -innovativeness, proactiveness and risk-taking- as affecting firm performance in different ways, thus raising questions on the influence of context on each EO dimension and, consequently, its effect on firm performance (Lomberg et al., 2017). Our reasoning departs from the idea, already stated by Rigtering et al. (2017), that the importance of both the entrepreneurial orientation and its dimensions varies across contexts and cultures. Therefore, we argue that context moderates the influence of EO on firm performance by affecting the importance of innovativeness, proactiveness, and risk-taking in configuring entrepreneurial orientation.

Individual and firm behavior is certainly influenced by the context in which they are embedded (Scott, 2003). Context can be understood in a broad sense as a particular set of cultural and institutional aspects both in their implicit and explicit forms. Regarding explicit forms, institutional environments "are characterized by the elaboration of rules and requirements to which individual organizations must conform in order to receive legitimacy and support" (Scott, 1995, p. 132). On the other hand, we can analyze the informal aspects of the environment from a cultural approach. Culture can be understood as a system of collective values allowing differentiation among members of different human groups (Hofstede, 1980). Finally, Institutional theory predicts the potential expectations that regulatory, social, and cultural influences may cast on a firm, thus shaping its actions to survive and legitimize its existence.

The aforementioned two levels of pressure affect firm entrepreneurial orientation. First, firm behavior is altered by the values of those responsible for a firm's decision-making processes. These values are consistent, to a certain extent, with the cultural environment of firm operation since entrepreneurship is a product of the social and cultural values of a given community (Huggins \& Thompson, 2014). Second, firm behavior is affected by an 
institutional environment featuring dominant types of ownership and non-ownership coordination, as well as of employment relations (Whitley, 1999; 2000). In this sense, cultural aspects and institutional arrangements within a certain geographical space lead to pattern variation in firm behavior, affecting aspects such as innovation strategies (Whitley, 2000). Consequently, it is reasonable to think that firm entrepreneurial behavior may vary across countries due to the differences in cultural, institutional, and market organizational features.

Cultural and institutional contexts may influence the importance of each dimension and their balance within the concept of EO (Rigtering et al., 2017). Therefore, the context in which firms operate may legitimize and encourage the pursuit of entrepreneurial opportunities (Reynolds et al., 1999; Fayolle, Basso, \& Bouchard, 2010). On the one hand, although there is some evidence that entrepreneurial activities are unevenly distributed across contexts (Bosma \& Schutjens, 2011), differences appear to be the cause of cultural variations across nations or regions (Ma \& Todorovic, 2012). Two opposite cultural and institutional contexts, for instance, could cause individual and firm behavior to show a high level of EO. One possible explanation of this is that the importance of each EO dimension varies across contexts (Lee, Lim, \& Pathak, 2011; Basco, Calabrò, \& Campopiano, 2018).

In this light, some cultural and institutional environments may be more closely aligned with some EO dimensions over others (Knight, 1997). As Lee and Peterson (2000) have predicted, cultural values and norms may either converge or conflict with a society's ability to develop a strong EO. Consequently, those cultures encouraging entrepreneurship may be "less tolerant of power distance, willing to accept living with uncertainty, are more individualistic, masculine, achievement oriented, and universalistic" (Lee \& Peterson, 2000). Therefore, potential impact of cultural and institutional patterns on Firm EO may be expected (e.g., Morris, Davis, \& Allen, 1994; Kreiser et al., 2010). That is, the weight of each dimension 
informing the concept of EO may vary across countries (Lomberg et al., 2017). Consequently, our second hypothesis shall be stated as follows:

Hypothesis 2: Entrepreneurial firm profiles vary according to the combinatory balance of innovation, proactiveness, and risk-taking as a consequence of ineludible institutional logic pressure.

Both the cross-context variance potential of entrepreneurial firm profiles and the importance of EO lie in their relationship with firm performance. In fact, scholarly theory indicates that firms benefit from encouraging risk-taking, proactiveness, and innovativeness attitudes given the effect of EO on firm performance (Filser et al., 2014; Shirokova et al., 2016). However, not all dimensions have the same impact on firm performance. Indeed, the combinatory potential of EO dimensions and its resulting impact are significantly variable (Rigtering et al., 2017). On such grounds, EO is conceptualized as a multidimensional composite construct (Covin, Green, \& Slevin, 2006). Despite the suggestion by various theoretical contributions of a connection between EO and firm performance, the empirical evidence is inconsistent with a potentially positive effect (for more information, see the literature review by Wales et al. (2013). Therefore, the extent to which each of the EO dimensions is linked to firm performance may be moderated by contextual factors (Lumpkin \& Dess, 1996b). That is, EO and firm performance are context-specific (Dess, Lumpkin, \& Covin, 1997). Consequently, the context in which firms are embedded is expected to act as a contingency dimension moderating the influence of entrepreneurial orientation on firm performance. In this light, our third hypothesis shall be formulated as follows:

Hypothesis 3: Context moderates the influence of entrepreneurial orientation in firm performance. 


\section{Methodology}

\subsection{The Contexts of China, Mexico and Spain}

The previous hypotheses have been tested in three different countries: China, Mexico, and Spain. Our gathering this particular sample responds to three main reasons. First, all three countries differ in several cultural dimensions (Hofstede, 1980). Second, they have different institutional patterns of development (Acemoglu \& Robinson, 2006). Finally, a growing importance of entrepreneurship is apparent in both at an economic and social scale (Stel, Van Carree, \& Thurik, 2005). Each of these countries thus has specific characteristics regarding their cultural and institutional environment.

Table 1 presents some data allowing a better understanding of these three countries' respective contexts, and their potential effect on firm entrepreneurial orientation. In this sense, the IMD World Competitiveness Center has created a ranking list of 63 countries based on a competitiveness index considering economic results, government and private sector efficiency, and national infrastructure. In 2017, China ranked 13th, Mexico, $51^{\text {st }}$, and Spain, 36th (IMD World Competitiveness Center, 2018). Competitive environments can certainly affect firm behavior and entrepreneurial orientation by supplying them with the competitive advantages essential for survival. Subsequently, an increasingly challenging competitive environment is expected to entail a proportional increase in the rates of firm entrepreneurial orientation as a response to such environment and other competitors.

Formal institutional environments may also affect firm entrepreneurial behavior in a specific context. Business activity in the three countries selected is conditioned by different legal and institutional regulations as well as particular historical, economic and political 
patterns (China, a capitalist market ruled by communist institutions, is one excellent example of such particularities). Along with the aforementioned formal context, an informal institutional environment (i. e. cultural context) can influence the way firms conceive and interpret entrepreneurial behavior. For instance, firm-scale, low risk-taking behavior may reflect a national-scale, culture-specific propensity to avoid uncertainty (Saeed et al., 2014). Additionally, table 1 compiles the features of the selected countries' entrepreneurial business environments (Global Entrepreneurship Monitor, 2017), thus providing a preliminary approach to the firms' context-specific business strategies and their consequences on entrepreneurial behavior.

\section{---INSERT TABLE 1 AROUND HERE---}

\subsection{Sample}

As previously stated, the sample for this study was collected from small and medium-sized firms in China, Mexico, and Spain. We have selected these countries to test our model because they illustrate three different contexts and can thus account for the invariance of the scale used to measure EO, while demonstrating the importance of each dimension in different environments, and revealing the specific moderating effect of EO on firm performance in each.

Data has been collected by means of an email survey targeting key informants, i.e., firm CEOs or owner-managers (a similar approach was used by Kreiser et al., 2002 and Rigtering et al., 2017). For China, we have focused on three main provinces: Shaanxi, Henan and Shandong. For Mexico, our research has been circumscribed to the State of Baja California. Finally, for Spain, a nation-wide scope has been applied - Since ours is a smalland medium-size firm target, firms have been retrieved from databases provided by each country's Chamber of Commerce. A random selection of companies has therefore been made, 
and the statistical power of the sample calculated with the $G^{*}$ Power 3.1.9.2 software tool (Faul, Erdfelder, Buchner, \& Lang, 2009). As a result, the power index for both the Chinese and Spanish firm samples amounts to 0.9486 , and that for the Mexican companies totals 0.9267, both values thus exceeding the threshold established by Cohen $(1988 ; 1992)$.

The questionnaire has originally been drafted in English, then translated into Spanish and Mandarin through a reverse translation process (Brislin, 1980). Teams of experts have duly reviewed the translation, making the necessary adaptations for the specific contexts of China, Spain, and Mexico. Subsequently, a pre-test has been carried out with a reduced sample of companies from each country. Throughout this process, some adjustments have been made to the questionnaire. To prevent key informant bias (Rong \&Wilkinson, 2011; Woodside, 2013), we've applied the procedure proposed by Kumar, Stern, \& Anderson (1993), making use of the LimeSurvey v. 2.5. software tool for this purpose. LimeSurvey is an open-code online application for survey devising purposes. It allows users to submit to each participant a personalized email message along with an institutional letter and a unique, firm-identified back-end link. Descriptive information about the fieldwork can be found in table 2 .

\section{---INSERT TABLE 2 AROUND HERE---}

The average size of the firms concerned differs among the three countries considered. The Chinese firms were the largest (66.3\% of the firms had over 250 employees), and the Spanish firms, the smallest (78.4\% of firms had between 10 and 49 employees). Most companies taking part in the survey belong to the industrial sector. Regarding the respondents' characteristics, most CEO participants are males. The highest percentage of male CEOs has been recorded in China (70\%), and the lowest, in Spain (55\%). All CEOs questioned have held their current position for over 25 years, a fact consistent with the 
private-owned nature of the firms. Finally, in terms of educational background, most CEOs in the three countries did not hold a Bachelor's Degree. The highest percentage of graduate CEOs was recorded among the Chinese firms (71\%), and the lowest among the Spanish firms $(63 \%)$

---INSERT TABLE 3 AROUND HERE---

\subsection{Measures}

\section{A dependent variable: firm performance}

We've measured firm performance using a 4-item scale, comprising the following firm performance figures from the previous year average annual-sale growth, market-share growth, profit growth, and capital-return growth (e.g., Wiklund \&Sheperd, 2005; Poon et al., 2006; Kellermanns, Eddleston, Sarathy, \& Murphy, 2012). Each item has been measured using fivepoint Likert's scale ( 1 for the lowest degree of agreement, and 5 for the highest). Thus, perception standards have been applied to measure the firms' performance. Our choice of a subjective measurement system responds to the difficulty in obtaining objective financial data from small- and medium-sized firms (Poon et al., 2006).

\section{An independent variable: entrepreneurial orientation}

We've measured EO using Miller's scale (1983) with the modifications introduced by Covin and Slevin (1989), and Covin and Miller (2014). Measuring EO involves three dimensions: innovation (3 items), proactivity (3 items), and risk assumption ( 3 items). This scale is intended to capture a firm's EO-related attitude, and it has been widely used, recording high scores of reliability and validity (Covin $\&$ Wales, 2012). Again, items have been measured on a five-point basis, usingLikert's scale (see Appendix A for a description of each item).

\section{A moderating variable: Context}


Context is considered a categorical moderator variable, the recorded value for which amounts to 1 in China, 2 in Mexico, and 3 in Spain.

\section{Control variables}

Several control variables have been used in this study, including each firm's age, size and activity sector (Pole \& Bondy, 2010). Our choice of these variables is grounded on their traditionally acknowledged influence on EO and firm performance (Lumpkin \&Dess, 1996a; Shirokova, Vega, \& Sokolova, 2013; Van Doorn, Jansen, Van den Bosch, \& Volberda, 2013; Wales, Parida, \& Patel, 2013). Firm age has been measured according to the number of yearly periods of activity since stablishment (Goosen, De Coning, \& Smit, 2002; Balabanis \&Katsikea, 2003; Luo, Zhou, \& Liu, 2005; Etchebarne, Geldres, \& García-Cruz, 2010). Firm size may influence firm EO (Balabanis \& Katsikea, 2003; Luo et al., 2005; Real, Roldán, \& Leal, 2014), and has been measured by the number of employee. Finally, in accordance with Zahra's finding (2008) that activity sectors influence the relationship between EO and firm performance, this variable has been applied considering three main economic sectors: industrial, services and construction (recording values of 1,2, and 3 respectively).

\subsection{Data analysis}

A partial-least-square, structural-equation model of (PLS-SEM) has been implemented to analyze the resulting data and contrast the hypotheses. The research conditions supporting this methodological choice are the following: 1) The fact that the variables used in the proposed model are composites (Rigdon, Sarsedt, \& Ringle, 2017; Sarstedt, Hair, Ringle, Thiele, \& Gudergan, 2016; Henseler, 2018); 2) The potential need to use second-order composites 
(Hair, Hult, Ringle, \& Sarsedt, 2017); and 3) The potentially small size of the sample (Richter et al., 2016). Data analysis has been performed using the SmartPLS 3.2.8 (Ringle et al., 2015) software tool. First, the general model proposed has been tested, proving the reliability and validity of the constructs. Subsequently, an invariance pattern has been detected in their measures (Henseler et al., 2016), leading us to conclude a cross-country- invariability of construct measures.

\section{Results}

For the purpose of our research, a two-phase procedure has been devised: first, a measurement model analysis, followed by a structural model analysis (Barclay, Higgins, \& Thompson, 1995). Such layout ensures scale validity and reliability before the main relationships (direct and moderation relationships) are contrasted.

\subsection{Measurement model assessment}

Following the recommendations made by Roldán and Sánchez-Franco (2012), our first step has consisted in processing the indicator loading values for the proposed model in each country. The associated parameters are shown in Table 4. Our conclusion at this stage is that all indicators have exceeded the threshold established at 0.7 by Carmines and Zeller (1979). Similarly, the minimum values for composite reliability, established at 0.7 by Fornell and Larcker (1981), for Cronbach's Alfa (0.7), and for Average Variance Extracted (AVE, recorded at 0.5$), 0.7$ for Cronbach's Alfa have been also exceeded. This has provided conclusive evidence for the model's sufficient construct validity i.e., the extent to which a set of measured items actually reflects the theoretical latent construct).

\section{---INSERT TABLE 4 AROUND HERE---}

Finally, we have analyzed the differences between the model composites through discriminant validity (Hair et al., 2017). To calculate discriminant validity, each composite's 
AVE square-root values have been compared with the correlations between the different composites of the model (Fornell \& Larcker, 1981). In all cases (see table 5), the AVE values exceed the corresponding squared inter-composite, correlational values (in the Chinese, Mexican and Spanish samples). Therefore, these results suggest a satisfactory discriminant validity for all constructs in the three samples.

---INSERT TABLE 5 AROUND HERE---

We have also analyzed the correlations between the various first and second composites (Table 6), concluding that the correlation between innovation, proactivity, and risk-taking is positive and significant for all three countries. There is also a positive and significant correlation between the EO dimensions (innovation, proactivity, and risk-taking) and both entrepreneurial orientation and firm performance, respectively. Finally, we have also noticed a positive and significant correlation between Entrepreneurial Orientation and firm performance.

---INSERT TABLE 6 AROUND HERE---

In conclusion, EO has been calculated as a type $b$, second-order composite from the latent variable scores (Wright, Campbell, Thatcher, \& Roberts, 2012), following the recommendations made by Diamantopoulos, Riefler, and Roth (2008). On the other hand, the main issue at stake when dealing with type b compounds is their collinearity problems (Diamantopoulos \&Winklhofer, 2001). Collinearity problems arise when the Variance Inflation Factor (VIF) records a value exceeding 5 (Hair et al., 2014). In our case, no collinearity problems were detected (see table 7).

---INSERT TABLE 7 AROUND HERE-

\subsection{Structural model analysis}


The structural analysis model have confirmed that the positive influence of entrepreneurial orientation on firm performance in the three countries selected (for China, Mexico, and Spain). In all cases, the path coefficients exceed 0.2 , a value indeed proposed as the minimum limit for such figures by Chin (1998). We have equally followed a bootstrap process (based on $\mathrm{t}(4,999)$, one-tailed test), revealing the aforementioned coefficients as significant since the $t$-values associated with them exceeded the value set for $t(4,999)$ in the one-tailed test (see table 8). Therefore, the first hypothesis may safely be confirmed.

\section{---INSERT TABLE 8 AROUND HERE---}

Three control variables are taken into consideration in this article: firm size (number of employees), age (years since firm establishment), and activity sector (see Table 8). For the Chinese and Mexican sub-samples, none of the control variables has proven to influence firm performance (with a path coefficient scoring below 0.2, and t-values lower than recommended) For the Spanish sub-sample, size has been concluded a significant variable, bearing a negative effect on firm performance (with a path coefficient score of 0.202 , and associated t-value of 3,550). Similarly, the activity-sector variable bears both a negative and significant effect, despite a path coefficient scoring below the 0.2 relevance threshold (Chin, 2010).

\section{---INSERT FIGURE 2 AROUND HERE---}

\subsection{Multigroup analysis}

To analyze the moderating effect of context on the relationship between entrepreneurial orientation and firm performance, the firms' national location shall be considered a moderating factor. In this case, a multigroup analysis procedure seems appropriate given the categorical variability of national locus. For this purpose, we've devised a comparative, twocountry approach, resulting in three comparisons: China-Mexico, China-Spain, and México- 
Spain. Before testing the moderating effect of national location, quantification of measurement invariance has been crucial. Measurement invariance is regarded as a major issue when conducting PLS-SEM multigroup analysis. To assess it, we have drawn on a MICOM (measurement invariance of composite models) procedure (Henseler et al., 2016), involving three steps.

First, configurational invariance interpreted both as a homogeneous parameterization system and way of estimation. To analyze configuration invariance, the measurement model, structural model and algorithm for all model estimates must be identical both for the integrity of each sample and for each group (relying on bothan identical questionnaire see Appendix and baseline model [Figure 1]). In our case, configuration invariance has been successfully attained, allowing us to turn to the next step -i.e., the analysis of composition invariance.

Second, compositional invariance (c), understood as a coefficient for indicator evenness. To assess compositional invariance, a MICOM procedure has been implemented through SmartPLS 3.2.8 software, involving a total of 5,000 permutations. As a result, $\mathrm{c}$ has scored values close to 1 , providing solid evidence for the occurrence of composition invariance (see Table 9). Additionally, a permutation test has allowed confirmation that none of the values for $\mathrm{c}$ differ significantly from this same figure. Therefore, we may safely conclude that composite invariance occurs in all constructs considered for our model. Finally, evenness between composite mean-related values and variance has been examined, for which purpose identity patterns between variance and means have been searched for. At this third stage, the results of the permutation test (5,000 permutations) corroborate the existence of evenness patterns between variance and means for all constructs considered (see Table 10 and 11).Conclusively enough, the aforementioned test has also showed that the resulting values do not significantly differ from cero (see table 12). 
---INSERT TABLE 9, 10 and 11 AROUND HERE---

\section{---INSERT TABLE 12 AROUND HERE---}

Once finalized, the three aforementioned procedures have allowed us to support the existence of a quantify measurement invariance. Consequently, the application of a multigroup analysis protocol has been pursued (Henseler et al., 2016). In this sense, depending on the country under analysis, innovation, proactivity and risk-taking shall affect entrepreneurial orientation differently. Hence, in China, proactivity has been proven the most salient dimension configuring entrepreneurial orientation, closely followed by innovation. Risk-taking is by far the least relevant dimension of entrepreneurial orientation in such country. In similar fashion, innovation has turned out the most relevant dimension among the Mexican companies selected, followed at great distance by proactivity and risk-taking. Finally, in Spain, all three dimensions of entrepreneurial orientation appear to be of similar importance, despite innovation being the most relevant. Therefore, our second hypothesis may be safely confirmed.

Thereafter, the path coefficients for each of the sub-samples have been calculated, allowing a subsequent estimation of significant differences within each block of comparison. Indeed, as can be seen in Table 8, substantial contrast between the resulting path coefficients has been discerned, thus confirming the moderating effect of national locus. On its part, EO is accountable for $54.7 \%$ of the incidence of variance in the Mexican firms' performance, $28.1 \%$ in that of Spanish firms, and $16.5 \%$, in that of Chinese companies. Consequently, our third hypothesis is thereby confirmed.

Once the moderating effect of national locus has been verified, its intensity should be verified through calculation of a statistical $\mathrm{f}^{2}$ coefficient (Henseler, Fassott, Dijkstra, \& Wilson, 2012). In our case, the $\mathrm{f}^{2}$-related value for the China-Mexico comparison was 0.28 , 
0.23 for China-Spain, and 0.19 for Mexico-Spain. According to Henseler et al. (2012), the threshold, $\mathrm{f}^{2}$-related values allowing quantification of moderating-effect intensity are the following: 0.02 for "weak", 0.15 for "moderate", and 0.35 for "strong". Therefore, we may state that national locus does have a moderating impact in all samples. To conclude our analysis, goodness of moderation has been estimated for each sub-sample by calculating a SRMR ratio (Standardized Root Mean Square Residual). The resulting values amount to 0.078 for the Chinese firms, 0.070 for the Mexican firms, and 0.075 for the Spanish companies (the threshold value being 0.08) (Henseler, Dijkstra, Sarstedt, Ringle, Diamantopoulos, Straub, \& Calantone, 2014). Therefore, there is sufficient evidence to support the suitability of our model.

\section{Discussion and conclusion}

This article has attempted to contextualize the concept of EO in three different countries (China, Mexico, and Spain), and to test each of these countries' moderating role in the relationship between EO and firm performance. As a starting point, we have hence taken the following research questions: Does EO influence firm performance? Does the importance of each EO dimension vary across countries? To what extent does a firm's context of operation affect the relationship between EO and firm performance? Regarding our theoretical framework, our first hypothesis has suggested a potential connection between EO and firm performance on the basis of the most recent EO-related literature. Our second hypothesis has drawn on institutional theory to argue that a firm's national context (with its cultural, economic, and social sources of pressure) may determine its behavior. Additionally, we have contended that multiple patterns of entrepreneurial performance exist, and that the different EO dimensions are subject to cross-context variance. Our third hypothesis, resulting from the 
previous ones, has proposed that the effect of $\mathrm{EO}$ on firm performance is moderated by the context.

The aforementioned hypotheses have been tested in three different countries - China, Mexico, and Spain—, framed in widely divergent cultural and institutional contexts. All of them offer exceptional environments in which to analyze and compare the concept of EO and its relationship with firm performance given the historical, cultural, institutional, and economic specificities of each. In general, our research has provided evidence of the universality of the concept of EO, its relationship with firm performance, and the importance of context.

First, we have found that EO influences positively firm performance. This gives evidence of the universal beneficial relationship between EO and firm performance with independence both of firm features and national locus. In this sense, our results are consistent with the literature review conducted by Wales et al. (2013) and Saeed et al. (2014). As a consequence, we may assert that entrepreneurial orientation acts as a reliable predictor of business success (Kraus et al., 2012) and, in addition, it has transcultural validity (Lomberg et al., 2017).

Second, taking into consideration the general relationship under study, and focusing on the importance of the context, this article is meant to prove that the contribution of each dimension comprised by EO concept differs according to each national context. In this sense, context brings to a better understanding what entrepreneurial firm means in different environments. Our results have proven that not all dimensions - innovativeness, proactiveness, and risk-taking — have the same importance across countries. Therefore, contextual features influence the relevance of each dimension included in entrepreneurial orientation. This result coincides with that obtained by Lomberg et al. (2017). 
In China, the risk-taking dimension is less relevant than either proactiveness and innovativeness in the country's particular configuration of entrepreneurial orientation. Innovation might be supported by a long-term orientation toward culture, while the importance of proactiveness might be sustained by a low-level avoidance of uncertainty. The Risk-taking dimension could be linked to the owners' economic and emotional attachment to the business. This situation positions both owners and managers in the type of losses resulting from their their risk behavior (Wiseman \& Gomez-Mejia, 1998).

In Mexico, proactiveness is the dimension bearing the lowest impact on the the multidimensional concept of entrepreneurial behavior. This could be explained by the high level of power differentials and uncertainty avoidance which may affect behavioral selfdetermination. The fact that the greatest influence of EO on firm performance may be observed in Mexico may be due to the existence of informal networks and a high tolerance to failure, promoting access to resources under attractive conditions (Stam \& Elfring, 2008). For Spain, our results show that, even though the comparability of the concept of EO in Spain and Mexico is high, Spain has a more balanced composition of all three EO dimensions. This could be explained by the fact that, beyond the cultural and institutional similarities between both countries, Spain has experienced a more steady economic, social and political development since its EU membership came into force. Within this particular context, EO in Spain is configured by a mixture of all three dimensions: risk-taking, proactiveness, and innovativeness.

Finally, this article demonstrates that the influence of the EO on firm performance varies considerably depending on the context. We agree with Wales, Gupta, and Mousa (2013), and with Kreiser et al. (2013), in the fact that context plays a moderating role in the influence of the EO on firm performance. The context not only affects the firm corporate 
behavior, but also the importance of a particular EO behavior for firm performance is also determined. These results are consistent with previous studies such as Wan (2005) and Semrau, Ambos, and Kraus (2016).

\subsection{Contributions}

This work has several theoretical and practical implications. First, it replicates previous studies dealing with the relationship between EO and firm performance and supplements prior research by examining this relationship in different cultural and institutional contexts. Thus, we believe to have addressed the call made by Welter (2011) concerning the need to contextualize the phenomenon of entrepreneurship by making entrepreneurship theory more context-sensitive. Specifically, following the urge to test differences in the concept of EO among diverse environments (e.g., Covin \& Miller, 2014),cultural and institutional contexts (Kiss et al. 2012), followed by the need to better understand the effect institutional context on entrepreneurial behavior (Veciana \& Urbano 2008), we have shed some light on the combinatory relevance of the risk-taking, proactiveness, and innovativeness dimensions to recontextualize the meaning of EO in different national contexts (Knight \& McCabe, 1997; Kreiser et al., 2010). Furthermore, we have demostrated that national locus seems to either strengthen or weaken each EO dimension and their relationship with firm performance (Boisot \& Meyer, 2008; Rui \& Yip, 2008). These results support the need for an institutional approach and reveal that institutions shape firm behavior.

Second, this article also addresses prior calls (e.g., Kreiser et al., 2002) to test the cross-cultural equivalence of EO by assessing its measurement invariance with Covin and Slevin's scale (1989). In line with previous studies (e.g., Madison, Runyan, \& Swinney,2014), we have tested measurement invariance following the recommendations made by Hansen et al. (2011). As a result, all EO dimensions have scored measurement values meeting the 
overall theoretical expectations in the three countries examined for this study. However, differences have emerged in the paths conditioning the importance of each dimension according to the national loci considered in this paper. Finally, we have offered a theoretical contribution to the debate on institutional theory, specifically on institutional logics. Taking into consideration that firms interact with their environment, it is our belief that context acts as an institutionalized, collective identity comprising multiple individual and firm connections (cognitive, normative, structural, and emotional) affecting firm behavior. By applying an institutional approach to pinpoint our research question, we believe to have responded to the call, made by Hansen et al. (2011), to explain the reasons behind the differential effects of entrepreneurial orientation on firm performance across countries.

Our findings also have direct implications for practitioners and policy makers. Regarding managerial implications, this research sheds some light on the essential dimensions of a firm, the recognition of which may encourage the development of an entrepreneurial culture. The environmental context seems to condition what dimensions are more salient for configuring firms' entrepreneurial orientation. Our results may also have implications for firms that attempt to internationalize their operation and must compete in different environments. Recognizing which EO dimensions are relevant in each context shall help firms to devise strategies for competitiveness. On the other hand, our article supports the policy makers' task since knowing the effect of context on a firm's entrepreneurial orientation features could help in the development and tailoring of entrepreneurial-culture policies by leveraging culturally relevant dimensions and hence stimulating firm EO.

\subsection{Limitations and future research}

Nevertheless, this paper presents a number of limitations, the overcoming of which can pinpoint new spaces for future research. One of its limitations lies in the consideration of 
entrepreneurial orientation as a type b, second-order composite. One could also analyze each of the three dimensions considered here as independent actors, and thus determine the influence of each dimension in different national environments. In this sense, it could be considered whether any of the EO dimensions is required for its effect on performance to take place. This aspect could be studied through the application of qualitative methods such as fsQCA (Kraus, Ribeiro-Soriano, \& Schüssler, 2018). The second limitation stems from the fact that we haven't considered the potential influence on EO of each firm's internal (competitive strategy, organizational structure, and dynamic capabilities, among others) and external variables (environmental features, the institutional framework and the degree of openness of an economy, among others). In this regard, future studies should explore the role of internal and external variables in the influence of EO on firm performance.

Third, our data is cross-sectional. Given the continuous changes experienced by all three countries, However, a longitudinal data analysis would be useful to spot potential differences in the results. The fourth limitation is the consideration of a multi-sectorial sample, so gathered in an attempt to give our results a more general scope, but it could be interesting to analyze the effect of entrepreneurial orientation on performance in a particular sector. Finally, it would be interesting to explore how employee behavior can be encouraged to ensure that an innovative, proactive, and risky orientation translates into sustainable competitive advantage over time (Poon et al., 2006). This would involve including variables based on individual traits and human resource practices. 


\section{References}

Acemoglu, D., \& Robinson, J. (2012). Why nations fail: The origins of power, prosperity, and poverty. New York, NY: Crown Business.

Acemoglu, D., \& Robinson, J. A. (2006). De Facto Political Power and Institutional Persistence. American Economic Review, 96(2), 325-330.

Anderson, B. S., Kreiser, P. M., Kuratko, D. F., Hornsby, J. S., \& Eshima, Y. (2015).

Reconceptualizing entrepreneurial orientation. Strategic Management Journal, 36(10), 1579-1596.

Balabanis, G. I., \& Katsikea, E. S. (2003). Being an entrepreneurial exporter: does it pay?. International Business Review, 12(2), 233-252.

Barclay, D., Higgins, C., \& Thompson, R. (1995). The Partial Least Squares (PLS) Approach to Causal Modeling: Personal Computer Adoption and Use as anIllustration. Technology Studies, 2(2), 285-309.

Basco, R. (2017). Epilogue: Multiple embeddedness contexts for entrepreneurship.In M. Ramírez-Pasilla, E. Brundin \& M. Markowska (Eds.). Contextualizing Entrepreneurship in developing and emerging economies. Cheltenham, UK; Northampton, MA: Edward Edgar Publishing.

Basco, R., Calabrò, A., \& Campopiano, G. (2018). Transgenerational Entrepreneurship Around the World: Implications for Family Business Research and Practice. Journal of Family Business Strategy. Onlinefirst.

Basso, O., Fayolle, A., \& Bouchard, V. (2009). Entrepreneurial orientation: The making of a concept. The International Journal of Entrepreneurship and Innovation, 10(4), 313-321.

Boisot, M., \& Meyer, M. W. (2008). Which way through the open door? Reflections on the internationalization of Chinese firms. Management and Organization Review, 4(3), 349- 
365.

Bosma, N., \& Schutjens, V. (2011). Understanding regional variation in entrepreneurial activity and entrepreneurial attitude in Europe. The Annals of Regional Science, 47(3), $711-742$.

Brislin, R. W. (1970). Back-translation for cross-cultural research. Journal of Cross-cultural Psychology, 1(3), 185-216.

Carmines, E. G., \& Zeller, R. A. (1979). Reliability and validity assessment. Beverly Hills, CA: Sage Publications.

Cavusgil, S. T., \& Knight, G. (2015). The born global firm: An entrepreneurial and capabilities perspective on early and rapid internationalization. Journal of International Business Studies, 46(1), 3-16.

Chandra, Y., Styles, C., \& Wilkinson, I. (2009). The recognition of first time international entrepreneurial opportunities: Evidence from firms in knowledge-based industries. International Marketing Review, 26(1), 30-61.

Chin, W. W. (1998). The partial least squares approach to structural equation modeling. Modern Methods for Business Research, 295(2), 295-336.

Borenstein, M., \& Cohen, J. (1988). Statistical power analysis: A computer program.Hilsdale, NJ: Laurence Erlbaum..

Cohen, J. (1992). A power primer. Psychological Bulletin, 112(1), 155-159.

Covin, J. G., Eggers, F., Kraus, S., Cheng, C. F., \& Chang, M. L. (2016). Marketing-related resources and radical innovativeness in family and non-family firms: A configurational approach. Journal of Business Research, 69(12), 5620-5627.

Covin, J. G., Green, K. M., \& Slevin, D. P. (2006). Strategic process effects on the entrepreneurial orientation-sales growth rate relationship. Entrepreneurship Theory and Practice, 30(1), 57-81. 
Covin, J. G., \& Miller, D. (2014). International Entrepreneurial Orientation: Conceptual Considerations, Research Themes, Measurement Issues, and Future Research Directions. Entrepreneurship Theory and Practice, 38(1), 11-44.

Covin, J. G., \& Slevin, D. P. (1989). Strategic Management of Small Firms in Hostile and Benign Environments. Strategic Management Journal, 10(1), 75-87.

Covin, J. G., \& Wales, W. J. (2012). The Measurement of Entrepreneurial Orientation. Entrepreneurship Theory and Practice, 36(4), 677-702.

Dess, G. G., Lumpkin, G. T., \& Covin, J. G. (1997). Entrepreneurial strategy making and firm performance: Tests of contingency and configurational models. Strategic Management Journal, 18(9), 677-695.

Diamantopoulos, A., Riefler, P., \& Roth, K. P. (2008). Advancing formative measurement models. Journal of Business Research, 61(12), 1203-1218.

Diamantopoulos, A., \& Winklhofer, H. M. (2001). Index construction with formative indicators: An alternative to scale development. Journal of Marketing Research, 38(2), $269-277$.

Engelen, A., Gupta, V., Strenger, L., \& Brettel, M. (2015). Entrepreneurial orientation, firm performance, and the moderating role of transformational leadership behaviors. Journal of Management, 41(4), 1069-1097.

Etchebarne, M. S., Geldres, V. V., \& García-Cruz, R. (2010). El impacto de la orientación emprendedora en el desempeño exportador de la firma. ESIC Market Economic and Business Journal, 137, 165-220.

Faul, F., Erdfelder, E., Buchner, A., \& Lang, A. G. (2009). Statistical power analyses using G*Power 3.1: Tests for correlation and regression analyses. Behavior Research Methods, 41(4), 1149-1160.

Fayolle, A., Basso, O., \& Bouchard, V. (2010). Three levels of culture and firms' 
entrepreneurial orientation: A research agenda. Entrepreneurship \& Regional Development, 22(7-8), 707-730.

Ferreira, J. J., Fernandes, C. I., \& Kraus, S. (2019). Entrepreneurship research: Mapping intellectual structures and research trends. Review of Managerial Science, 13(1), 181205.

Filser, M., Eggers, F., Kraus, S., \& Málovic, É. (2014). The effect of financial resource availability on entrepreneurial orientation, customer orientation and firm performance in an international context: An empirical analysis from Austria and Hungaria. Journal of East European Management Studies, 19(1), 7-30.

Fornell, C., \& Larcker, D. F. (1981). Evaluating structural equation models with unobservable variables and measurement error. Journal of Marketing Research, 18(1), 77-90.

De Coning, T. J., Goosen, C. J., \& Smit, E. D. M. (2002). Corporate entrepreneurship and financial performance: The role of management. South African Journal of Business Management, 33(4), 21-27.

Global Entrepreneurship Monitor (2017). Global Report 2016/2017. Global Entrepreneurship Research Association (GERA), London: London Business School, UK.

Hair Jr, J. F., Hult, G. T. M., Ringle, C., \& Sarstedt, M. (2017). A primer on partial least squares structural equation modeling (PLS-SEM) (2nd edition). Los Ángeles, CA: Sage Publications.

Hansen, J. D., Deitz, G. D., Tokman, M., Marino, L. D., \& Weaver, K. M. (2011). Crossnational invariance of the entrepreneurial orientation scale. Journal of Business Venturing, 26(1), 61-78.

Henseler, J. (2018). Partial least squares path modeling: Quo vadis? Quality \& Quantity, $52(1), 1-8$.

Henseler, J., Dijkstra, T. K., Sarstedt, M., Ringle, C. M., Diamantopoulos, A., Straub, D. W... 
\& Calantone, R. J. (2014). Common Beliefs and Reality About PLS Comments on Rönkkö and Evermann (2013). Organizational Research Methods, 17(2), 182-209. Henseler, J., Fassott, G., Dijkstra, T. K., \& Wilson, B. (2012). Analysing quadratic effects of formative constructs by means of variance-based structural equation modelling. European Journal of Information Systems, 21(1), 99-112.

Henseler, J., Hubona, G., \& Ray, P. A. (2016). Using PLS path modeling in new technology research: Updated guidelines. Industrial Management \& Data Systems, 116(1), 2-20.

Hernandez-Perlines, F. (2018). Moderating effect of absorptive capacity on the entrepreneurial orientation of international performance of family businesses. Journal of Family Business Management, 8(1), 58-74.

Hernández-Perlines, F., Moreno-García, J., \& Yañez-Araque, B. (2016). The mediating role of competitive strategy in international entrepreneurial orientation. Journal of Business Research, 69(11), 5383-5389.

Hernández-Perlines, F., Moreno-García, J., \& Yáñez-Araque, B. (2019). The influence of socioemotional wealth in the entrepreneurial orientation of family businesses. International Entrepreneurship and Management Journal, 15(2), 523-544.

Hofstede, G. (1980). Culture's consequences: International differences in work-related values. Beverly Hills, CA: Sage Publications.

Huggins, R., \& Thompson, P. (2014). Culture, entrepreneurship and uneven development: A spatial analysis. Entrepreneurship \& Regional Development, 26(9-10), 726-752.

IMD World Competitiveness Center (2018): The 2018 IMD World Competitiveness Ranking. Lausanne, Switzerland.

Kellermanns, F. W., Eddleston, K. A., Sarathy, R., \& Murphy, F. (2012). Innovativeness in family firms: A family influence perspective. Small Business Economics, 38(1), 85-101. Kiss, A. N., Danis, W. M., \& Cavusgil, S. T. (2012). International entrepreneurship research 
in emerging economies: A critical review and research agenda. Journal of Business Venturing, 27(2), 266-290.

Kleinbaum, D. G., Kupper, L. L., Muller, K. E., \& Nizam, A. (1988). One-way analysis of variance. In Applied regression analysis and other multivariable methods (pp. 341-386). Boston, MA: PWS-Kent Publishing Co.

Knight, F. H. (1921). Risk, uncertainty and profit. New York, NY: Hart, Schaffner and Marx.

Knight, G. A. (1997). Cross-cultural reliability and validity of a scale to measure firm entrepreneurial orientation. Journal of Business Venturing, 12(3), 213-225.

Kraus, S., Ribeiro-Soriano, D., \& Schüssler, M. (2018). Fuzzy-set qualitative comparative analysis (fsQCA) in entrepreneurship and innovation research-the rise of a method. International Entrepreneurship and Management Journal, 14(1), 15-33.

Kraus, S., Rigtering, J. C., Hughes, M., \& Hosman, V. (2012). Entrepreneurial orientation and the business performance of SMEs: A quantitative study from the Netherlands. Review of Managerial Science, 6(2), 161-182.

Kreiser, P.,Marino, L., Kuratko, D., \&Weaver, K. M. (2013). Disaggregating entrepreneurial orientation: The non-linear impact of innovativeness, proactiveness and risk-taking on sme performance. Small Business Economics, 40(2), 273-291.

Kreiser, P. M., Marino, L. D., \& Weaver, K. M. (2002). Assessing the psychometric properties of the entrepreneurial orientation scale: A multi-country analysis. Entrepreneurship Theory and Practice, 26(4), 71-94.

Kropp, F., Lindsay, N. J., \& Shoham, A. (2006). Entrepreneurial, market, and learning orientations and international entrepreneurial business venture performance in South African firms. International Marketing Review, 23(5), 504-523.

Kumar, N., Stern, L. W., \& Anderson, J. C. (1993). Conducting interorganizational research using key informants. Academy of Management Journal, 36(6), 1633-1651. 
Lechner, C., \& Gudmundsson, S. V. (2014). Entrepreneurial orientation, firm strategy and small firm performance. International Small Business Journal, 32(1), 36-60.

Lee, S., Lim, S., \& Pathak, R. (2011). Culture and entrepreneurial orientation: A multicountry study. International Entrepreneurship and Management Journal, 7(1), 1-15.

Lee, S. M., \& Peterson, S. J. (2000). Culture, entrepreneurial orientation, and global competitiveness. Journal of World Business, 35(4), 401-416.

Lomberg, C., Urbig, D., Stöckmann, C., Marino, L. D., \& Dickson, P. H. (2017). Entrepreneurial orientation: The dimensions' shared effects in explaining firm performance. Entrepreneurship Theory and Practice, 41(6), 973-998.

Lumpkin, G. T., \& Dess, G. G. (1996a). Clarifying the entrepreneurial orientation construct and linking it to performance. Academy of Management Review, 21(1), 135-172.

Lumpkin, G. T., \& Dess, G. G. (1996b). Enriching the entrepreneurial orientation construct Reply to Entrepreneurial orientation or pioneer advantage'. Academy of Management Review, 21(3), 605-607.

Lumpkin, G. T., \& Dess, G. G. (2001). Linking two dimensions of entrepreneurial orientation to firm performance: The moderating role of environment and industry life cycle. Journal of Business Venturing, 16(5), 429-451.

Luo, X., Zhou, L., \& Liu, S. S. (2005). Entrepreneurial firms in the context of China's transition economy: an integrative framework and empirical examination. Journal of Business Research, 58(3), 277-284.

Ma, J., \& Todorovic, Z. W. (2012). Understanding the role of entrepreneurial quality and national culture on the economic development. International Journal of Entrepreneurship and Small Business, 16(3), 299-313.

Madison, K., Runyan, R. C., \& Swinney, J. L. (2014). Strategic posture and performance: Revealing differences between family and nonfamily firms. Journal of Family Business 
Strategy, 5(3), 239-251.

Merz, G.R. \& Sauber, M.H. (1995). Profiles of managerial activities in small firms. Strategic Management Journal, 16, 551-564.

Miller, D. (1983). The Correlates of Entrepreneurship in Three Types of Firms. Management Science, 29(7), 770-791.

Miller, D., \& Friesen, P. H. (1983). Strategy-making and environment: The third link. Strategic Management Journal, 4(3), 221-235.

Morris, M. H., Davis, D. L., \& Allen, J. W. (1994). Fostering Corporate Entrepreneurship: Cross-Cultural Comparisons of the Importance of Individualism versus Collectivism. Journal of International Business Studies, 25(1), 65-89.

North, D. C. (1990). Institutions, institutional change and economic performance. Cambridge, UK: Cambridge university press.

Pole, J. D., \& Bondy, S. J. (2011). Control Variables. In J. A. Salemes (Ed.). Encyclopedia of Research Design. Chicago, IL: American Library Association.

Poon, J. M., Ainuddin, R. A., \& Junit, S. O. H. (2006). Effects of self-concept traits and entrepreneurial orientation on firm performance. International Small Business Journal, 24(1), 61-82.

Real, J. C., Roldán, J. L., \& Leal, A. (2014). From entrepreneurial orientation and learning orientation to business performance: Analysing the mediating role of organizational learning and the moderating effects of organizational size. British Journal of Management, 25(2), 186-208.

Reynolds, P. D., Hay, M., \& Camp, S. M. (1999). Global entrepreneurship monitor. Kansas City, Mo.: Kauffman Center for Entrepreneurial Leadership.

Richter, N. F., Sinkovics, R. R., Ringle, C. M., \& Schlaegel, C. (2016). A critical look at the use of SEM in international business research. International Marketing Review, 33(3), 
376-404.

Rigdon, E. E., Sarstedt, M., \& Ringle, C. M. (2017). On comparing results from CB-SEM and PLS-SEM: Five perspectives and five recommendations. Marketing ZFP, 39(3), 4-16.

Rigtering, J. C., Eggers, F., Kraus, S., \& Chang, M. L. (2017). Entrepreneurial orientation, strategic planning and firm performance: The impact of national cultures. European Journal of International Management, 11(3), 301-324.

Ringle, C. M., Wende, S., \& Becker, J. M. (2015). SmartPLS 3. Boenningstedt, GM: SmartPLS GmbH, http://www. smartpls.com (last visited on 08/27/2018).

Rodrigo-Alarcón, J., Parra-Requena, G., \& García-Villaverde, P. M. (2014). Efectividad de la orientación emprendedora: el papel del capital social y las capacidades. Investigaciones Europeas de Dirección Y Economía de La Empresa, 20(3), 131-139.

Roldán, J. L., \& Sánchez-Franco, M. J. (2012). Variance-based structural equation modeling: guidelines for using partial least squares. In Information Systems Research, in Research Methodologies, Innovations and Philosophies in Software Systems Engineering and Information Systems, (pp.193-221). IGI Global.

Rong, B., \& Wilkinson, I. F. (2011). What do managers' survey responses mean and what affects them? The case of market orientation and firm performance. Australasian Marketing Journal (AMJ), 19(3), 137-147.

Rosenbusch, N., Brinckmann, J., \& Bausch, A. (2011). Is innovation always beneficial? A meta-analysis of the relationship between innovation and performance in SMEs. Journal of Business Venturing, 26(4), 441-457.

Rui, H., \& Yip, G. S. (2008). Foreign acquisitions by Chinese firms: A strategic intent perspective. Journal of World Business, 43(2), 213-226.

Saeed, S., Yousafzai, S. Y., \& Engelen, A. (2014). On cultural and macroeconomic contingencies of the entrepreneurial orientation-performance relationship. 
Entrepreneurship Theory and Practice, 38(2), 255-290.

Sarstedt, M., Hair, J. F., Ringle, C. M., Thiele, K. O., \& Gudergan, S. P. (2016). Estimation issues with PLS and CBSEM: Where the bias lies! Journal of Business Research, 69(10), 3998-4010.

Scott, W. R. (1995). Institutions and organizations. Thousand Oaks, CA: SAGE.

Scott, W. R. (1992). Organizations: Rational, natural and open systems $\left(3^{\text {rd }}\right.$ ed.). Englewood Cliffs, NJ [etc.]: Printice Hall International.

Schumpeter, J. A., \& Opie, R. (1934). The theory of economic development: An inquiry into profits, capital, credit, interest, and the business cycle ( $3^{\text {rd }}$ ed.). Cambridge, MA: Harvard University Press.

Shirokova, G., Bogatyreva, K., Beliaeva, T., \& Puffer, S. (2016). Entrepreneurial orientation and firm performance in different environmental settings: contingency and configurational approaches. Journal of Small Business and Enterprise Development, 23(3), 703-727.

Shirokova, G., Vega, G., \& Sokolova, L. (2013). Performance of Russian SMEs: Exploration, exploitation and strategic entrepreneurship. Critical perspectives on international business, 9(1/2), 173-203.

Semrau, T., Ambos, T., \& Kraus, S. (2016). Entrepreneurial orientation and SME performance across societal cultures: An international study. Journal of Business Research, 69(5), 1928-1932.

Stam, W., \& Elfring, T. (2008). Entrepreneurial orientation and new venture performance: The moderating role of intra- and extraindustry social capital. Academy of Management Journal, 51(1): 97-111

Stel, A., Van Carree, M., \& Thurik, R. (2005). The Effect of Entrepreneurial Activity on National Economic Growth. Small Business Economics, 24(3), 311-321. 
Stetz, P. E., Howell, R., Stewart, A., Blair, J. D., \& Fottler, M. D. (2000).

Multidimensionality of entrepreneurial firm-level processes: Do the dimensions covary? Frontiers of Entrepreneurship Research.

Van Doorn, S., Jansen, J. J., Van den Bosch, F. A., \& Volberda, H. W. (2013).

Entrepreneurial orientation and firm performance: Drawing attention to the senior team. Journal of Product Innovation Management, 30(5), 821-836.

Veciana, J., \& Urbano, D. (2008). The institutional approach to entrepreneurship research. Introduction. International Entrepreneurship and Management Journal, 4(4), 365-379.

Wales, W.J. (2016). Entrepreneurial orientation: A review and synthesis of promising research directions. International Small Business Journal, 34(1), 3-15.

Wales, W., Monsen, E., \& McKelvie, A. (2011). The Organizational Pervasiveness of Entrepreneurial Orientation. Entrepreneurship Theory and Practice, 35(5), 895-923.

Wales, W. J., Gupta, V. K., \& Mousa, F. -T. (2013). Empirical research on entrepreneurial orientation: An assessment and suggestions for future research. International Small Business Journal, 31(4), 357-383.

Wales, W. J., Parida, V., \& Patel, P. C. (2013). Too much of a good thing? Absorptive capacity, firm performance, and the moderating role of entrepreneurial orientation. Strategic Management Journal, 34(5), 622-633.

Wan, W. P. (2005). Country resource environments, firm capabilities, and corporate diversification strategies. Journal of Management Studies, 42(1), 161-182.

Welter, F. (2011). Contextualizing Entrepreneurship-Conceptual Challenges and Ways Forward. Entrepreneurship Theory and Practice, 35(1), 165-184.

Whitley, R. (1999). Divergent capitalisms: The social structuring and change of business systems. Oxford, UK: Oxford University Press.

Whitley, R. (2000). The Institutional Structuring of Innovation Strategies: Business Systems, 
Firm Types and Patterns of Technical Change in Different Market Economies. Organization Studies, 21(5), 855-886.

Wiseman, R., \& Gomez-Mejia, L. (1998). A Behavioral Agency Model of Managerial Risk Taking. The Academy of Management Review, 23(1), 133-153

Wiklund, J., \& Shepherd, D. (2005). Entrepreneurial orientation and small business performance: a configurational approach. Journal of Business Venturing, 20(1), 71-91.

Wong, P. K., Ho, Y. P., \& Autio, E. (2005). Entrepreneurship, innovation and economic growth: Evidence from GEM data. Small Business Economics, 24(3), 335-350.

Woodside, A. G. (2013). Moving beyond multiple regression analysis to algorithms: Calling for adoption of a paradigm shift from symmetric to asymmetric thinking in data analysis and crafting theory. Journal of Business Research, 66(4), $463-472$.

Wright, R. T., Campbell, D. E., Thatcher, J. B., \& Roberts, N. (2012). Operationalizing multidimensional constructs in structural equation modeling: Recommendations for IS research. Communications of the Association for Information Systems, 30(1), 367-412.

Yusuf, A. (2002). Environmental Uncertainty, the Entrepreneurial Orientation of Business Ventures and Performance. International Journal of Commerce and Management, 12(3/4), 83-103.

Zahra, S. A. (2008). Being entrepreneurial and market driven: Implications for company performance. Journal of Strategy and Management, 1(2), 125-142. 
Figure 1:

\section{Conceptual model}

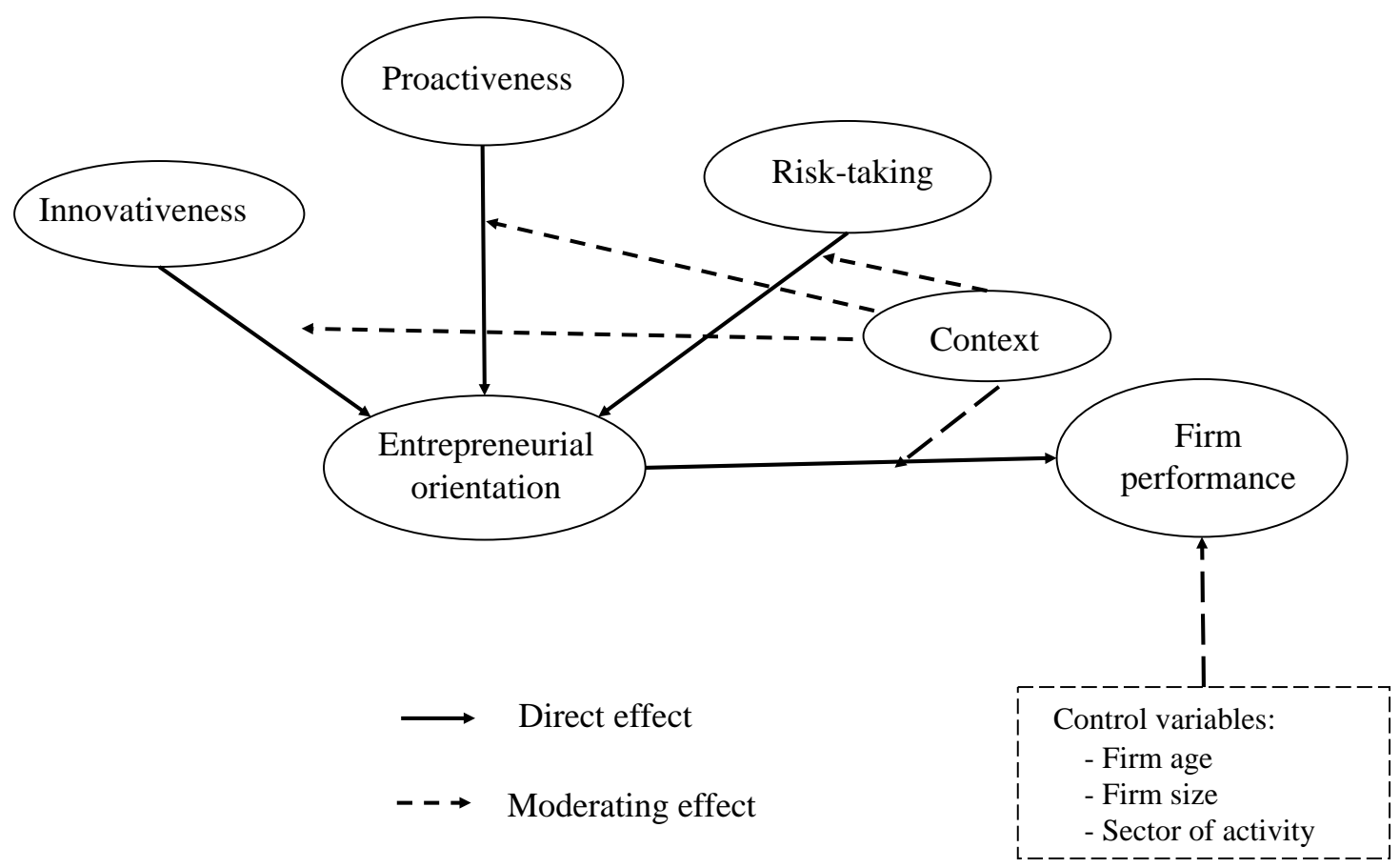


Figure 2:

\section{Structural model}

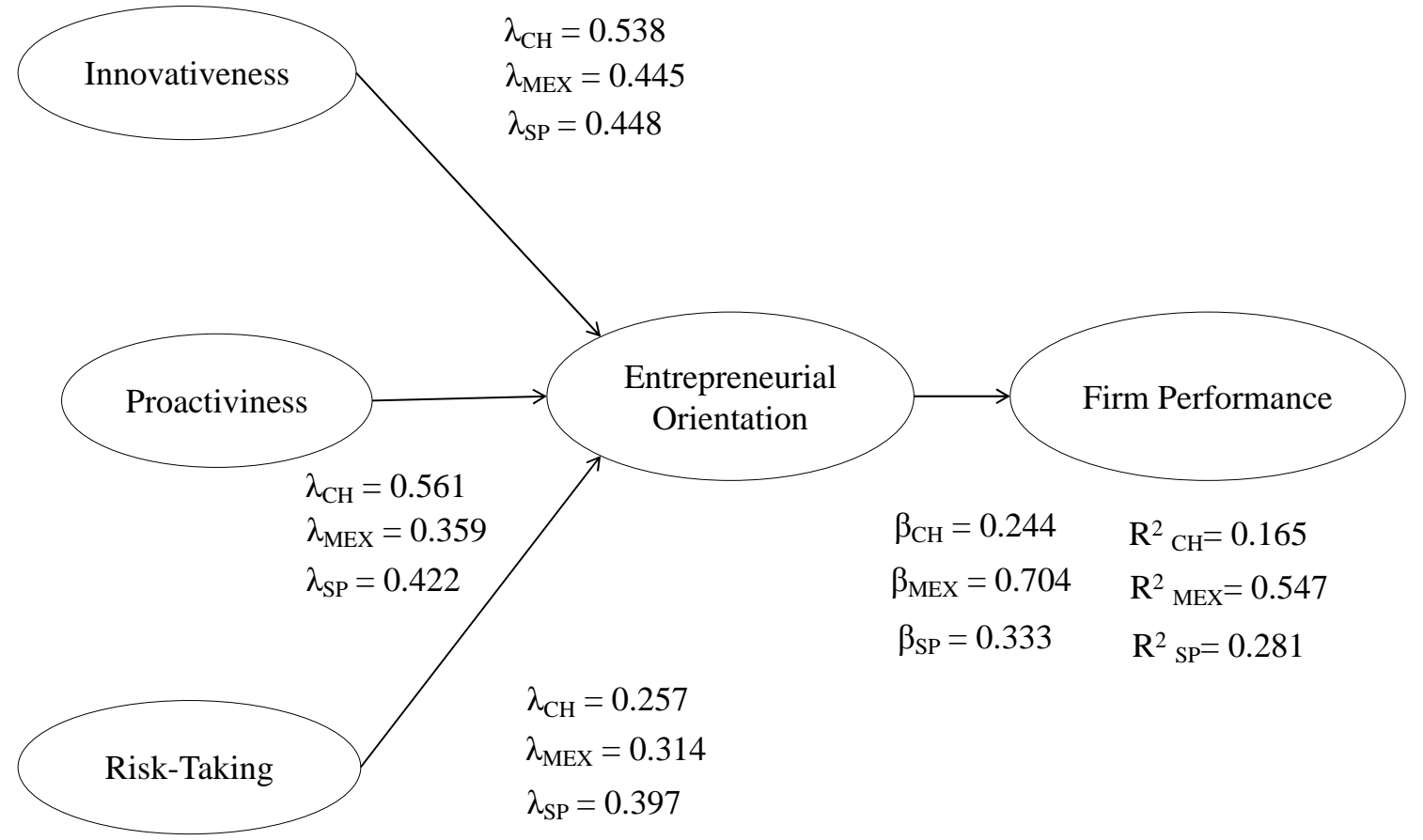


Table 1:

Cultural and institutional differences among China, Mexico, and Spain

\begin{tabular}{|c|c|c|c|}
\hline & China & Mexico & Spain \\
\hline \multicolumn{4}{|l|}{ General country's information } \\
\hline Form of government & Communist & $\begin{array}{c}\text { Federal } \\
\text { Republic }\end{array}$ & $\begin{array}{l}\text { Parliamentary } \\
\text { Monarchy }\end{array}$ \\
\hline Geographic location & Asia & North America & Europe \\
\hline Cultural cluster & Confucian Asia & Latin America & Latin Europe \\
\hline \multicolumn{4}{|l|}{ Hofstede's cultural index } \\
\hline Power distance & High & High & Moderate \\
\hline Individualism & Low & Low & Moderate \\
\hline Masculinity & High & High & Moderate \\
\hline Uncertainty avoidance & Low & High & High \\
\hline Long-term orientation & High & Low & Moderate \\
\hline \multicolumn{4}{|c|}{$\begin{array}{l}\text { GEM } 2017 / 18 \text { - Entrepreneurial business environment } \\
(1=\text { highly insufficient, } 9 \text { = highly sufficient })\end{array}$} \\
\hline Entrepreneurial Finance & 5.45 & 4.33 & 4.14 \\
\hline Government Policies: Support and Relevance & 4.67 & 5.23 & 3.39 \\
\hline Government Policies: Taxes and Bureaucracy & 4.27 & 3.92 & 2.94 \\
\hline Government Entrepreneurship Programs & 4.73 & 5.30 & 4.88 \\
\hline Entrepreneurial Education at School Stage & 3.22 & 2.56 & 2.95 \\
\hline Entrepreneurial Education at Post School Stage & 5.06 & 5.86 & 4.66 \\
\hline R\&D Transfer & 4.25 & 4.34 & 3.74 \\
\hline Commercial and Legal Infrastructure & 4.43 & 5.01 & 4.80 \\
\hline Internal Market Dynamics & 7.13 & 4.65 & 4.04 \\
\hline Internal Market Burdens or Entry Regulation & 4.38 & 3.99 & 3.69 \\
\hline Physical Infrastructures & 7.23 & 6.56 & 5.93 \\
\hline Cultural and Social Norms & 5.27 & 4.91 & 3.80 \\
\hline
\end{tabular}

Source: Global Entrepreneurship Monitor (2017) and IMD World Competitiveness Center (2018). 
Table 2:

Fieldwork technical datasheet

\begin{tabular}{lccc}
\hline & China & Mexico & Spain \\
\hline Sample size & 2205 & 1032 & 1494 \\
Responses & 114 & 102 & 114 \\
Sampling procedure & Simple random & Simple random & Simple random \\
Confidence level & $95 \%, \mathrm{p}=\mathrm{p}=50 \%, \alpha=$ & $95 \%, \mathrm{p}=\mathrm{p}=50 \%, \alpha=$ & $95 \%, \mathrm{p}=\mathrm{p}=50 \%, \alpha=$ \\
& 0.05 & 0.05 & 0.05 \\
Response & $5.17 \%$ & $9.88 \%$ & $7.63 \%$ \\
Sampling error & $8.94 \%$ & $9.22 \%$ & 8.82 \\
\end{tabular}


Table 3:

General sample information

\begin{tabular}{|c|c|c|c|c|c|c|c|}
\hline & \multicolumn{2}{|c|}{ China $^{1}$} & \multicolumn{2}{|c|}{ Mexico $^{2}$} & \multicolumn{2}{|c|}{ Spain $^{3}$} \\
\hline & & $\mathrm{N}$ & $\%$ & $\mathrm{~N}$ & $\%$ & $\mathrm{~N}$ & $\%$ \\
\hline \multirow[t]{2}{*}{ Gender } & Male & 79 & 69.29 & 66 & 64.7 & 65 & 55.26 \\
\hline & Female & 35 & 30.71 & 36 & 35.3 & 51 & 44.74 \\
\hline \multirow[t]{2}{*}{ Age } & $<25$ & 47 & 41.22 & 20 & 29.41 & 30 & 26.31 \\
\hline & $>25$ & 67 & 58.78 & 72 & 70.59 & 84 & 73.69 \\
\hline \multirow[t]{2}{*}{ Studies } & No university & 81 & 71.05 & 70 & 68.62 & 76 & 66.67 \\
\hline & University & 33 & 28.95 & 32 & 31.38 & 38 & 33.33 \\
\hline \multirow[t]{3}{*}{ Employees } & $10-49$ & 13 & 11.2 & 46 & 45.09 & 90 & 78.94 \\
\hline & $50-249$ & 26 & 22.5 & 26 & 25.49 & 18 & 15.78 \\
\hline & $>250$ & 76 & 66.3 & 30 & 29.42 & 6 & 5.28 \\
\hline \multirow[t]{3}{*}{ Sector } & primary & 0 & 0.0 & 14 & 13.72 & 10 & 8.77 \\
\hline & Industry & 68 & 59.1 & 57 & 55.88 & 53 & 46.49 \\
\hline & Services & 47 & 40.9 & 31 & 30.40 & 51 & 44.74 \\
\hline
\end{tabular}

1 Rules for defining SMEs: State Economic and Trade Commission, the State Planning Commission, the Ministry of Finance and the National Bureau of Statistics (2003).

2 Circular office No. UNGP / TU/ 0427/2009, of July 1, 2009 of the Ministry of Public Administration.

3 Recommendation 2003/361/CE of the European Commission on May 6, 2003 about the definition of micro, small and medium enterprises (European Commission, 2003). 
Table 4:

Indicator loading and composite reliability of variables and indicators

\begin{tabular}{|c|c|c|c|c|c|c|c|c|c|c|c|c|}
\hline \multirow[t]{2}{*}{ Items/dimensions } & \multicolumn{3}{|c|}{ Indicator Loading } & \multicolumn{3}{|c|}{ Composite Reliability } & \multicolumn{3}{|c|}{ Cronbach's Alpha } & \multicolumn{3}{|c|}{$A V E$} \\
\hline & China & Mexico & Spain & China & Mexico & Spain & China & Mexico & Spain & China & Mexico & Spain \\
\hline \multicolumn{4}{|c|}{ Innovativeness (first-order composite mode a) } & 0.857 & 0.908 & 0.853 & 0.753 & 0.848 & 0.744 & 0.669 & 0.767 & 0.660 \\
\hline Innovativeness 1 & 0.847 & 0.865 & 0.731 & & & & & & & & & \\
\hline Innovativeness 2 & 0.887 & 0.878 & 0.870 & & & & & & & & & \\
\hline Innovativeness 3 & 0.709 & 0.883 & 0.830 & & & & & & & & & \\
\hline \multicolumn{4}{|c|}{ Proactiveness (first-order composite mode a) } & 0.741 & 0.749 & 0.832 & 0.782 & 0.749 & 0.702 & 0.506 & 0.689 & 0.624 \\
\hline Proactiveness 1 & 0.592 & 0.718 & 0.792 & & & & & & & & & \\
\hline Proactiveness 2 & 0.912 & 0.926 & 0.818 & & & & & & & & & \\
\hline Proactiveness 3 & 0.579 & 0.713 & 0.758 & & & & & & & & & \\
\hline \multicolumn{4}{|c|}{ Risk taking (first-order composite mode a) } & 0.791 & 0.877 & 0.870 & 0.743 & 0.791 & 0.776 & 0.567 & 0.704 & 0.691 \\
\hline Risk taking 1 & 0.859 & 0.874 & 0.790 & & & & & & & & & \\
\hline Risk taking 2 & 0.821 & 0.859 & 0.854 & & & & & & & & & \\
\hline Risk taking 3 & 0.539 & 0.782 & 0.848 & & & & & & & & & \\
\hline \multicolumn{4}{|c|}{ Firm Performance (first-order composite mode a) } & 0.700 & 0.982 & 0.793 & 0.756 & 0.975 & 0.703 & 0.575 & 0.931 & 0.608 \\
\hline Firm Performance 1 & 0.778 & 0.962 & 0.929 & & & & & & & & & \\
\hline Firm Performance 2 & 0.707 & 0.967 & 0.822 & & & & & & & & & \\
\hline Firm Performance 3 & 0.621 & 0.966 & 0.712 & & & & & & & & & \\
\hline Firm Performance 4 & 0.709 & 0.905 & 0.775 & & & & & & & & & \\
\hline
\end{tabular}




\section{Table 5:}

\section{Discriminant validity}

\begin{tabular}{lrrrrrrrrr}
\hline & \multicolumn{3}{c}{ CHINA } & \multicolumn{3}{c}{ MEXICO } & \multicolumn{3}{c}{ SPAIN } \\
& 1 & 2 & 3 & 1 & 2 & 3 & 1 & \multicolumn{1}{c}{2} & 3 \\
\hline 1. Innovativeness & $0.817^{*}$ & & & $0.870^{*}$ & & & $0.812^{*}$ & & \\
2. Proactiveness & 0.477 & $0.711^{*}$ & & 0.777 & $0.830^{*}$ & & 0.636 & $0.789^{*}$ & \\
3. Risk taking & 0.367 & 0.390 & $0.752^{*}$ & 0.686 & 0.580 & $0.829^{*}$ & 0.544 & 0.553 & $0.831^{*}$ \\
\hline
\end{tabular}

(*) The square root of the AVE. 
Table 6:

Inter-composite covariances

\begin{tabular}{|c|c|c|c|c|c|}
\hline \multicolumn{6}{|l|}{ CHINA } \\
\hline & Innovativeness & Proactiveness & Risk-taking & $\begin{array}{l}\text { Entrepreneurial } \\
\text { Orientation }\end{array}$ & $\begin{array}{l}\text { Firm } \\
\text { Performance }\end{array}$ \\
\hline \multicolumn{6}{|l|}{ Innovativeness } \\
\hline Proactiveness & 0.5766 & & & & \\
\hline Risk-taking & 0.4720 & 0.4869 & & & \\
\hline $\begin{array}{l}\text { Entrepreneurial } \\
\text { Orientation }\end{array}$ & 0.5347 & 0.4981 & 0.4723 & & \\
\hline $\begin{array}{l}\text { Firm } \\
\text { Performance }\end{array}$ & 0.5132 & 0.4623 & 0.4980 & 0.5562 & \\
\hline \multicolumn{6}{|l|}{ MEXICO } \\
\hline & Innovativeness & Proactiveness & Risk-taking & $\begin{array}{r}\text { Entrepreneurial } \\
\text { Orientation }\end{array}$ & $\begin{array}{r}\text { Firm } \\
\text { Performance } \\
\end{array}$ \\
\hline \multicolumn{6}{|l|}{ Innovativeness } \\
\hline Proactiveness & 0.5212 & & & & \\
\hline Risk-taking & 0.4349 & 0.4790 & & & \\
\hline $\begin{array}{l}\text { Entrepreneurial } \\
\text { Orientation }\end{array}$ & 0.5448 & 0.5408 & 0.5142 & & \\
\hline $\begin{array}{l}\text { Firm } \\
\text { Performance }\end{array}$ & 0.4898 & 0.5103 & 0.5438 & 0.4790 & \\
\hline \multicolumn{6}{|l|}{ SPAIN } \\
\hline & Innovativeness & Proactiveness & Risk-taking & $\begin{array}{r}\text { Entrepreneurial } \\
\text { Orientation } \\
\end{array}$ & $\begin{array}{r}\text { Firm } \\
\text { Performance } \\
\end{array}$ \\
\hline \multicolumn{6}{|l|}{ Innovativeness } \\
\hline Proactiveness & 0.5120 & & & & \\
\hline Risk-taking & 0.4824 & 0.4814 & & & \\
\hline $\begin{array}{l}\text { Entrepreneurial } \\
\text { Orientation }\end{array}$ & 0.5567 & 0.5348 & 0.5340 & & \\
\hline $\begin{array}{l}\text { Firm } \\
\text { Performance }\end{array}$ & 0.5575 & 0.5127 & 0.5652 & 0.5793 & \\
\hline
\end{tabular}

Notes: $\mathrm{p}<0.001$ (based on $\mathrm{t}(4,999)$, one-tailed test). 
Table 7:

Collinearity statistics for entrepreneurial orientation

\begin{tabular}{lcccccc}
\hline \multirow{2}{*}{ Factor } & \multicolumn{2}{c}{ CHINA } & \multicolumn{2}{c}{ MEXICO } & \multicolumn{2}{c}{ SPAIN } \\
& Weights $(\lambda)$ & IVF & Weights $(\lambda)$ & IVF & Weights $(\lambda)$ & IVF \\
\hline Innovativeness & 0.538 & 1.403 & 0.445 & 3.197 & 0.448 & 1.403 \\
Proactiveness & 0.561 & 1.660 & 0.359 & 2.548 & 0.422 & 1.660 \\
Risk-taking & 0.257 & 1.258 & 0.314 & 1.910 & 0.397 & 1.258 \\
\hline
\end{tabular}


Table 8:

Results of the structural model and control variables

\begin{tabular}{|c|c|c|c|c|c|c|c|c|c|}
\hline & \multicolumn{3}{|c|}{ Firm performance } & \multicolumn{2}{|c|}{ Age } & \multicolumn{2}{|c|}{ Sector } & \multicolumn{2}{|c|}{ Size } \\
\hline & $\beta$ & t-value & $\mathrm{R}^{2}$ & $\beta$ & t-value & $\beta$ & t-value & $\beta$ & $\mathrm{t}$-value \\
\hline China & 0.244 & $11.315^{* * *}$ & 0.165 & -0.099 & $0.670^{\text {n.s. }}$ & -0.212 & $0.525^{\text {n.s. }}$ & -0.058 & $0.403^{\text {n.s. }}$ \\
\hline Spain & 0.333 & $5.645 * * *$ & 0.281 & 0.220 & $0.123^{\text {n.s. }}$ & -0.011 & $3.657 * * *$ & -0.202 & $3.550 * * *$ \\
\hline
\end{tabular}

Notes: *** $\mathrm{p}<0.001$ (based on $\mathrm{t}(4,999)$, one-tailed test).

n.s.- not significant 
Table 9:

MICOM: Compositional invariance

\begin{tabular}{|c|c|c|c|c|c|c|c|c|c|}
\hline & & CHINA-MEXICO & & & CHINA-SPAIN & & & MEXICO-SPAIN & \\
\hline Composite & c-value $(0=1)$ & $\begin{array}{c}95 \% \text { confidence } \\
\text { interval }\end{array}$ & $\begin{array}{c}\text { Compositional } \\
\text { invariance? }\end{array}$ & c-value $(0=1)$ & $\begin{array}{c}95 \% \text { confidence } \\
\text { interval }\end{array}$ & $\begin{array}{c}\text { Compositional } \\
\text { invariance? }\end{array}$ & c-value $(0=1)$ & $\begin{array}{c}95 \% \text { confidence } \\
\text { interval }\end{array}$ & $\begin{array}{c}\text { Compositional } \\
\text { invariance? }\end{array}$ \\
\hline INNOV & 0.999 & {$[0.997 ; 1.000]$} & Yes & 0.999 & [0.997;1.000] & Yes & 0.999 & {$[0.996 ; 1.000]$} & Yes \\
\hline PROACT & 0.996 & {$[0.993 ; 1.000]$} & Yes & 0.992 & [0.989;1.000] & Yes & 0.996 & {$[0.993 ; 1.000]$} & Yes \\
\hline RISK-TAK & 0.998 & [0.996;1.000] & Yes & 0.999 & [0.996;1.000] & Yes & 0.998 & {$[0.996 ; 1.000]$} & Yes \\
\hline $\mathrm{EO}$ & 0.998 & {$[0.997 ; 1.000]$} & Yes & 0.999 & [0.997;1.000] & Yes & 0.997 & {$[0.995 ; 1.000]$} & Yes \\
\hline FIRMPERF & 0.994 & {$[0.991 ; 1.000]$} & Yes & 0.994 & {$[0.990 ; 1.000]$} & Yes & 0.998 & {$[0.996 ; 1.000]$} & Yes \\
\hline
\end{tabular}

Note: For procedure MICOM use the program SmartPLS 3.2.8 for 5,000 permutations. 
Table 10:

MICOM: Equal variances

\begin{tabular}{|c|c|c|c|c|c|c|c|c|c|}
\hline & & CHINA-MEXICO & & & CHINA-SPAIN & & & MEXICO-SPAIN & \\
\hline Composite & $\begin{array}{l}\text { Diference of the } \\
\text { compsite's } \\
\text { variance ratio } \\
\quad(=0)\end{array}$ & $\begin{array}{c}95 \% \text { confidence } \\
\text { interval }\end{array}$ & $\begin{array}{c}\text { Equal } \\
\text { variances? }\end{array}$ & $\begin{array}{l}\text { Diference of the } \\
\text { compsite's } \\
\text { variance ratio } \\
\quad(=0)\end{array}$ & $\begin{array}{c}95 \% \text { confidence } \\
\text { interval }\end{array}$ & $\begin{array}{c}\text { Equal } \\
\text { variances? }\end{array}$ & $\begin{array}{l}\text { Diference of the } \\
\text { compsite's } \\
\text { variance ratio } \\
\quad(=0)\end{array}$ & $\begin{array}{c}95 \% \text { confidence } \\
\text { interval }\end{array}$ & $\begin{array}{c}\text { Equal } \\
\text { variances? }\end{array}$ \\
\hline INNOV & 0.999 & [0.997;1.000] & Yes & 0.001 & {$[-0.228 ; 0.232]$} & Yes & -0.001 & {$[-0.238 ; 0.210]$} & Yes \\
\hline PROACT & 0.996 & {$[0.993 ; 1.000]$} & Yes & 0.002 & {$[-0.226 ; 0.219]$} & Yes & -0.008 & {$[-0.215 ; 0.199]$} & Yes \\
\hline RISK-TAK & 0.998 & [0.996;1.000] & Yes & 0.001 & {$[-0.240 ; 0.227]$} & Yes & -0.007 & {$[-0.228 ; 0.221]$} & Yes \\
\hline EO & 0.998 & {$[0.997 ; 1.000]$} & Yes & 0.001 & {$[-0.225 ; 0.236]$} & Yes & -0.004 & {$[-0.227 ; 0207]$} & Yes \\
\hline FIRMPERF & 0.994 & [0.991;1.000] & Yes & 0.004 & {$[0.222 ; 0.237]$} & Yes & -0.003 & {$[0.206 ; 0.208]$} & Yes \\
\hline
\end{tabular}

Note: For procedure MICOM use the program SmartPLS 3.2.8 for 5,000 permutations. 
Table 11:

MICOM: Equal means

\begin{tabular}{|c|c|c|c|c|c|c|c|c|c|}
\hline & & CHINA-MEXICO & & & CHINA-SPAIN & & & MEXICO-SPAIN & \\
\hline Composite & $\begin{array}{l}\text { Diference of the } \\
\text { compsite's } \\
\text { variance ratio } \\
\qquad(=0)\end{array}$ & $\begin{array}{c}95 \% \text { confidence } \\
\text { interval }\end{array}$ & Equal means? & $\begin{array}{l}\text { Diference of the } \\
\text { compsite's } \\
\text { variance ratio } \\
\quad(=0)\end{array}$ & $\begin{array}{c}95 \% \text { confidence } \\
\text { interval }\end{array}$ & Equal means? & $\begin{array}{l}\text { Diference of the } \\
\text { compsite's } \\
\text { variance ratio } \\
\quad(=0)\end{array}$ & $\begin{array}{c}95 \% \text { confidence } \\
\text { interval }\end{array}$ & Equal means? \\
\hline INNOV & -0.001 & {$[-0.225 ; 0.218]$} & Yes & -0.003 & {$[-0.450 ; 0.430]$} & Yes & 0.001 & {$[-0.275 ; 0.259]$} & Yes \\
\hline PROACT & 0.001 & {$[-0.220 ; 0.216]$} & Yes & -0.009 & {$[-0.343 ; 0.312]$} & Yes & 0.004 & {$[-0.221 ; 0.210]$} & Yes \\
\hline RISK-TAK & -0.001 & {$[-0.213 ; 0.221]$} & Yes & 0.001 & {$[-0.365 ; 0.392]$} & Yes & 0.002 & {$[-0.190 ; 0.189]$} & Yes \\
\hline EO & -0.001 & {$[-0.218 ; 0.225]$} & Yes & -0.004 & {$[-0.444 ; 0.421]$} & Yes & 0.002 & {$[-0.202 ; 0.202]$} & Yes \\
\hline FIRMPERF & -0.004 & {$[-0.220 ; 0.225]$} & Yes & 0.001 & {$[-0.275 ; 0.297]$} & Yes & 0.003 & {$[-0.327 ; 0.332]$} & Yes \\
\hline
\end{tabular}

Note: For procedure MICOM use the program SmartPLS 3.2.8 for 5,000 permutations. 
Table 12:

Multigroup analysis test results

\begin{tabular}{|c|c|c|c|c|c|c|c|}
\hline & China & Mexico & $\begin{array}{l}\text { Diff. (China } \\
\text { vs. Mexico) }\end{array}$ & $\begin{array}{c}\text { tParametic } \\
(\mathrm{EV})\end{array}$ & $\begin{array}{c}\text { t }_{\text {Parametric }} \\
(\mathrm{NEV})\end{array}$ & $\mathrm{P}_{\text {permutation }}$ & $\mathrm{P}_{\text {Henseler }}$ \\
\hline \multirow[t]{2}{*}{$\mathrm{EO}>\mathrm{FP}$} & 0.244 & 0.704 & -0.460 & $3.801^{\mathrm{a}}$ & $3.979^{\mathrm{a}}$ & $0.068^{b}$ & $0.051^{\mathrm{c}}$ \\
\hline & China & Spain & $\begin{array}{c}\text { Diff. (China } \\
\text { vs. Spain) }\end{array}$ & $\begin{array}{c}t_{\text {Parametic }} \\
(\mathrm{EV})\end{array}$ & $\begin{array}{c}\mathrm{t}_{\text {Parametric }} \\
(\mathrm{NEV})\end{array}$ & $\mathrm{P}_{\text {permutation }}$ & $\mathrm{P}_{\text {Henseler }}$ \\
\hline \multirow[t]{2}{*}{$\mathrm{EO}>\mathrm{FP}$} & 0.244 & 0.333 & -0.089 & 2.632 & $2.652^{\mathrm{a}}$ & $0.067^{b}$ & $0.052^{\mathrm{c}}$ \\
\hline & Mexico & Spain & $\begin{array}{r}\text { Diff. (Mexico } \\
\text { vs. Spain) } \\
\end{array}$ & $\begin{array}{r}t_{\text {Parametic }} \\
(\mathrm{EV}) \\
\end{array}$ & $\begin{array}{r}t_{\text {Parametric }} \\
(\mathrm{NEV}) \\
\end{array}$ & $\mathrm{P}_{\text {permutation }}$ & $\mathrm{P}_{\text {Henseler }}$ \\
\hline $\mathrm{EO}>\mathrm{FP}$ & 0.704 & 0.333 & 0.371 & $3.513^{\mathrm{a}}$ & $3.513^{\mathrm{a}}$ & $0.026^{b}$ & $0.024^{\mathrm{c}}$ \\
\hline
\end{tabular}

Notes: ${ }^{a}$ Significant (one-tailed $\mathrm{t}$ distribution, one-sided test), ${ }^{\mathrm{b}}$ significant at $0.10,{ }^{\mathrm{c}}$ significant (one-sided test). 


\section{Appendix}

\section{Questionnaire}

\section{Entrepreneurial Orientation}

\section{Innovativeness}

1. My company favors a strong emphasis on $R \& D$, technological development and innovation.

2. In the last 5 years, my company has started new businesses or introduced new products.

3. My company has often made dramatic changes to products and services.

\section{Proactiveness}

1. My company typically responds to the actions initiated by competitors and rarely initiates changes in their sector.

2. My organization is often the first business to introduce new products or services, administrative techniques, operating technologies, etc.

3. My organization typically seeks to avoid competitive clashes, preferring a "live-and-let-live" posture.

\section{Risk Taking}

1. My company prefers to engage in investment projects with moderate risk because expectations for returns are better.

2. Given the dynamic environment, my company prefers to engage in investments that show incremental behavior, starting with small investments and gradually increasing the commitment of resources.

3. When confronted with decision-making situations involving uncertainty, my firm typically adopts a cautious, "wait-and-see" posture in order to minimize the probability of making costly decisions.

\section{Firm Performance}

1. Average annual sales growth in the last year

2. Growth of market share in the last year

3. Profit growth in the last year

4. Growth in the return on capital 
$\mathrm{PhD}$. Rodrigo Basco is currently an associate professor at American University of Sharjah (AUS)-United Arab Emirates and holds the Sheikh Saoud bin Khalid bin Khalid Al-Qassimi Chair in Family Business. His research focuses on entrepreneurship, management, and regional development with special interest in family firms, and he has taught economics, management, and family business courses at universities in Spain, Chile, and Germany. His research has been published in international academic journals, including Family Business Review, European Management Journal, Journal of Management \& Organization, and International Small Business Journal, among others. Dr. Basco recently edited a special issue of the Journal of Family Business Strategy on the topic "Family Business and Regional Development," and he is an editorial board member for several leading journals. Before joining AUS, Dr. Basco was a postdoctoral scholar at the Witten Institute for Family Business at the University of Witten/Herdecke in Germany. He was also a visiting researcher at the University of Edinburgh (Scotland) and at CeFEO at Jonkoping University as well as a visiting professor at Valladolid University (Spain) and at IMT School for Advanced Studies Lucca (Italy). He also blogs actively about family business topics for a general audience on his Family Firm Blog.

Felipe Hernández-Perlines is $\mathrm{PhD}$ in Economics and Business. He is a professor of Strategic Management in the Department of Business Administration at the University of Castilla-La Mancha (Spain). He has been a visiting professor at universities in Italy, France, Mexico and the United States. His research has focused on agri-food cooperatives, family businesses and the tourism sector. His work has been published in journals such as Journal Business Research, R\&D Management, European Journal of International Management, Psychology \& Marketing, Frontiers in Psychology, Management Decision, European Journal of International Management, International Journal of Contemporary Hospitality Management and International Journal of Hospitality Management.

María Rodríguez-García is a PhD student in Business Administration at the University of Valencia (Spain). Her research is focused in the entrepreneurship line of research, highlighting green entrepreneurship. On the other hand, she is advancing in family firms research. Among her research projects we can stand out SPRING (Succession Planning and Regeneration In Family Businesses for New Growth), a project under the light of the European Union in which the University of Valencia acts as a partner; and collaboration in the academic scope for INEKA Conference. She is Editorial Assistant of International Journal of Intellectual Property Rights and Collaborator at the Chair "Entrepreneurship: Being student to entrepreneur"-Grupo Maicerías Españolas-Arroz DACSA and the Faculty of Economics (Valencia). 